\title{
Reply to 'Comment on 'The burden of occupationally-related cutaneous malignant melanoma in Britain due to solar radiation" - outdoor occupation may not be linked to increased risk of melanoma in Britain
}

Lesley Rushton ${ }^{\star}, 1$ and Sally J Hutchings ${ }^{1}$

${ }^{1}$ Department of Epidemiology and Biostatistics, Imperial College London, MRC-PHE Centre for Environment and Health, Norfolk Place, London W2 1PG, UK

Sir,

Our study aimed to provide an estimate of the contribution of solar radiation exposure experienced at work to the overall burden of cutaneous malignant melanoma (CMM) in Britain (Rushton and Hutchings, 2017). The International Agency for Research on Cancer has classified solar radiation as a group 1 definite human carcinogen that causes CMM as well as other forms of skin cancer (IARC, 2012).

In his letter to the Editor, the author suggests that our choice of risk estimate was from a study whose results of a positive association contrast with those of a meta-analysis by Chang et al (2009) that found no association with workplace solar radiation and CMM in high latitude countries. It should be noted that Chang et al also found that high occupational sun exposure at low latitudes was associated with increased risk of CMM on the head and neck compared with low exposure (odds ratio $(\mathrm{OR})=1.7 ; 95 \%$ confidence interval $(\mathrm{CI})$ : 1.0-3.0). Among the recent studies we reviewed, in our paper, some showed a strong association of workplace exposure, for example, ORs of 3.02 (95\% CI: 1.88-4.86) for melanoma in situ and 1.97 (95\% CI 1.43-2.71) for invasive melanoma for duration of work $>5$ years (Trakatelli et al, 2016), and others no association, for example, the Australian study by Vuong et al (2014).

As we point out in our paper, the evidence for the role of occupational solar radiation of exposure thus remains equivocal, but given that solar radiation per se is an established human carcinogen, a contribution from occupational exposure seems plausible. Our results have drawn attention to the importance of solar radiation exposure generally and in several industry sectors. The study also highlights the long latency of cancers such as CMM, and therefore the need to encourage the use of sunscreens and protective clothing during outdoor work to prevent future cancers occurring.

The current literature consists of studies of with different designs and quality with often poorly characterised populations and exposure information. Personal sensors that connect remotely to mobile phones and laptops are now becoming available, and offer the potential to gather and track environmental data such as UV in real time. New studies that take advantage of the improved technology to obtain more accurate exposure information are needed to evaluate the contribution of occupational UV exposure to CMM and other skin cancers.

\section{CONFLICT OF INTEREST}

The authors declare no conflict of interest.

\section{REFERENCES}

Chang Y, Barrett JH, Bishop DT, Armstrong BK, Bataille V, Bergman W, Berwick M, Bracci PM, Elwood JM, Ernstoff MS, Gallagher RP, Green AC, Gruis NA, Holly EA, Ingvar C, Kanetsky PA, Karagas MR, Lee TK, Le Marchand L, Mackie RM, Olsson H, Østerlind A, Rebbeck TR, Sasieni P, Siskind V, Swerdlow AJ, Titus-Ernstoff L, Zens MS, Newton-Bishop JA (2009) Sun exposure and melanoma risk at different latitudes: a pooled analysis of 5700 cases and 7216 controls. Int J Epidemiol 38(3): 814-830.

IARC (2012) Radiation: volume 100D, a review of human carcinogens. In IARC Monographs on the Evaluation of Carcinogenic Risk to Humans. International Agency for Research on Cancer: Lyon, France.

Rushton L, Hutchings SJ (2017) The burden of occupationally-related cutaneous malignant melanoma in Britain due to solar radiation. Br J Cancer 116(4): 536-539.

Trakatelli M, Barkitzi K, Apap C, Majewski S, De Vries E, EPIDERM group (2016) Skin cancer risk in outdoor workers: a European multicenter case-control study. J Eur Acad Dermatol Venereol 30(Suppl. 3): 5-11.

Vuong K, McGeechan K, Armstring BK, AMFS Investigators, GEM Investigators, Cust AE (2014) Occupational sun exposure and risk of melanoma according to anatomical site. Int J Cancer 134: 2735-2741.

This work is published under the BJC's standard license to publish agreement. After 12 months the license terms will change to a Creative Commons AttributionNonCommercial-Share Alike 4.0 Unported License.

*Correspondence: Dr L Rushton; E-mail: I.rushton@imperial.ac.uk

Published online 16 March 2017

(C) 2017 Cancer Research UK. All rights reserved 0007 - 0920/17 